\title{
A dual-function fluorescent probe for detection of hydrogen sulfide and water content in dimethyl sulfoxide
}

Hao Wang, Yanan Li, Shaoxiang Yang*, Hongyu Tian, Sen Liang and Baoguo Sun

Beijing Advanced Innovation Center for Food Nutrition and Human Health, Beijing Technology and Business University, Beijing 100048, PR of China

*E-mail: yangshaoxiang@th.btbu.edu.cn

\begin{tabular}{|c|c|}
\hline TABLE OF CONTENTS & PAGE \\
\hline The fluorescent test approach & S2 \\
\hline Figure S1. ${ }^{1} \mathrm{H}$ NMR spectra of Probe 1 & S3 \\
\hline Figure S2. ${ }^{13} \mathrm{C}$ NMR spectra of Probe 1 & S3 \\
\hline Figure S3. The fluorescence intensity of Probe $1-\mathrm{H}_{2} \mathrm{~S}$ in $\mathrm{CH}_{3} \mathrm{CN}$-water & S4 \\
\hline Figure S4. The fluorescence intensity of Probe $1-\mathrm{H}_{2} \mathrm{~S}$ in $\mathrm{C}_{2} \mathrm{H}_{5} \mathrm{OH}$-water & S4 \\
\hline Figure S5. ${ }^{1} \mathrm{H}$ NMR titration spectra of Probe $1-\mathrm{H}_{2} \mathrm{~S}$ & S5 \\
\hline Figure S6. HMQC spectra of compound 1 & S5 \\
\hline Figure S7. HMQC spectra of Probe $1-\mathrm{H}_{2} \mathrm{~S}$ & S6 \\
\hline Figure S8. ${ }^{1} \mathrm{H}$ NMR titration spectra of compound $1-\mathrm{H}_{2} \mathrm{~S}$ & S7 \\
\hline Figure S9. HPLC spectra of Probe $1-\mathrm{H}_{2} \mathrm{~S}$ & S7 \\
\hline Figure S10. MS spectra of compound 1 & S8 \\
\hline Figure S11. MS spectra of compound 3 & S8 \\
\hline Figure S12. MS spectra of compound 6 & S9 \\
\hline Figure S13. MS spectra of compound 7 & S9 \\
\hline Figure S14. The fluorescence intensity of compound 1 & S10 \\
\hline
\end{tabular}




\section{The fluorescent test approach}

Preparation of solutions of Probe 1 and analytes

DMSO, as a reagent, was used to dissolve Hcy, Probe 1, Cys and GSH. After mixing, a Probe 1 stock solution was obtained. The analytes Hydrazine, $\mathrm{Na}_{2} \mathrm{~S}, \mathrm{PhSNa}, \mathrm{KI}$, $\mathrm{NaHSO}_{3}, \mathrm{CaCl}_{2}, \mathrm{NaCl}, \mathrm{H}_{2} \mathrm{O}_{2}, \mathrm{NaF}, \mathrm{Na}_{2} \mathrm{SO}_{3}, \mathrm{NaBr}, \mathrm{NH}_{4} \mathrm{Cl}$ and $\mathrm{MgSO}_{4}$ were dissolved in distilled water to obtained $10 \mathrm{mM}$ aqueous solutions. Various concentrations could be obtained by diluting these stock solutions with distilled water.

\section{The procedures of $\mathrm{H}_{2} \mathrm{~S}$ determination}

Preparation of the test system: $0.02 \mathrm{~mL}$ probe solution was added to a cuvette. Then, ethanol was poured into the cuvette to make up a volume of $2 \mathrm{~mL}$. Finally, ion solution was added. After waiting a few minutes, it was mixed completely. Samples of mixture were analyzed in the fluorescence spectrometer using the conditions of $\lambda_{\mathrm{ex}}=425 \mathrm{~nm}$, $\lambda_{\text {em }}=487 \mathrm{~nm}$, temperature $=25^{\circ} \mathrm{C}$, voltage $=500 \mathrm{~V}$, and slit widths $=5 \mathrm{~nm}, 5 \mathrm{~nm}$. 
Figure S1. ${ }^{1} \mathrm{H}$ NMR spectra of Probe 1

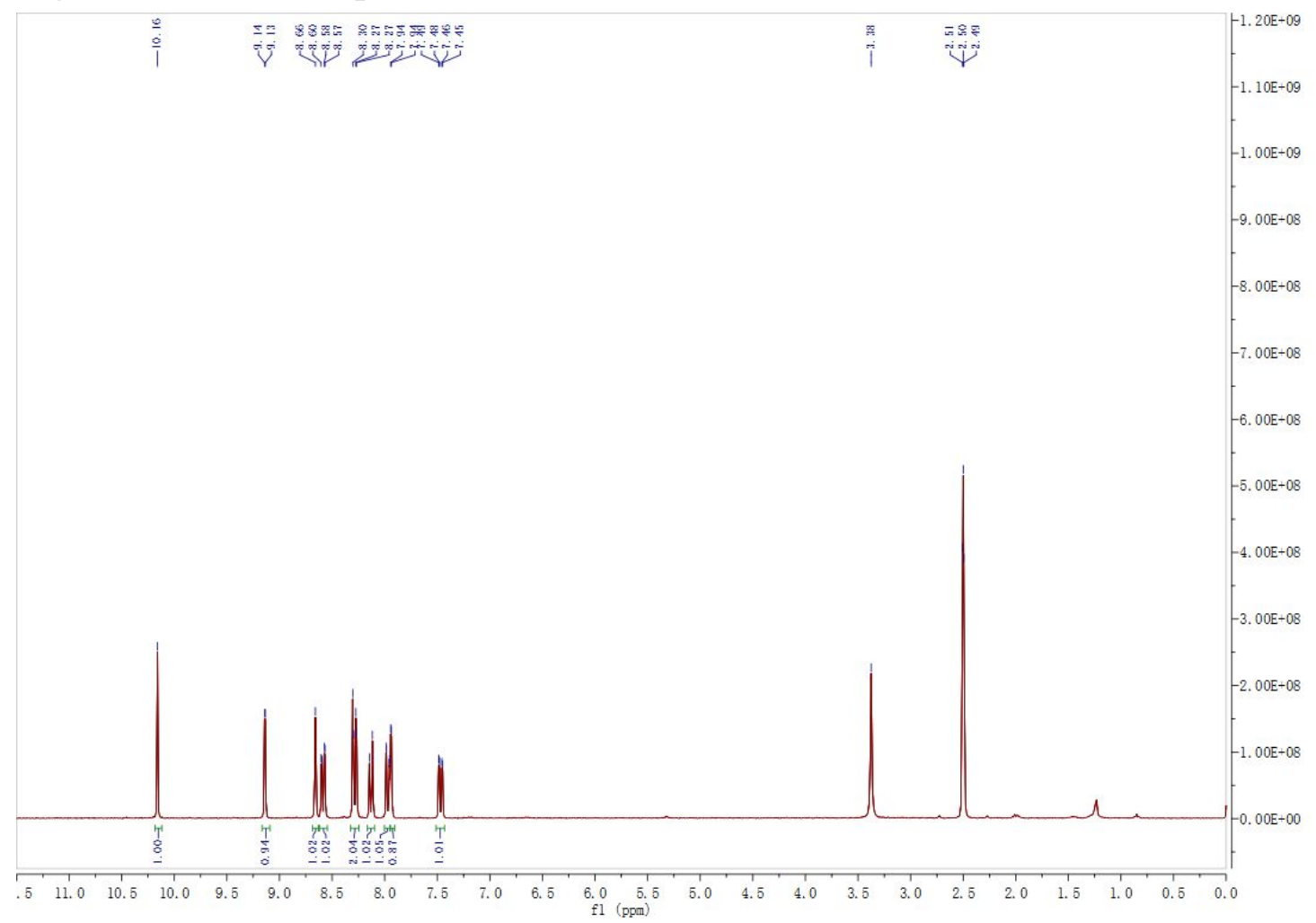

Figure S2. ${ }^{13} \mathrm{C}$ NMR spectra of Probe 1

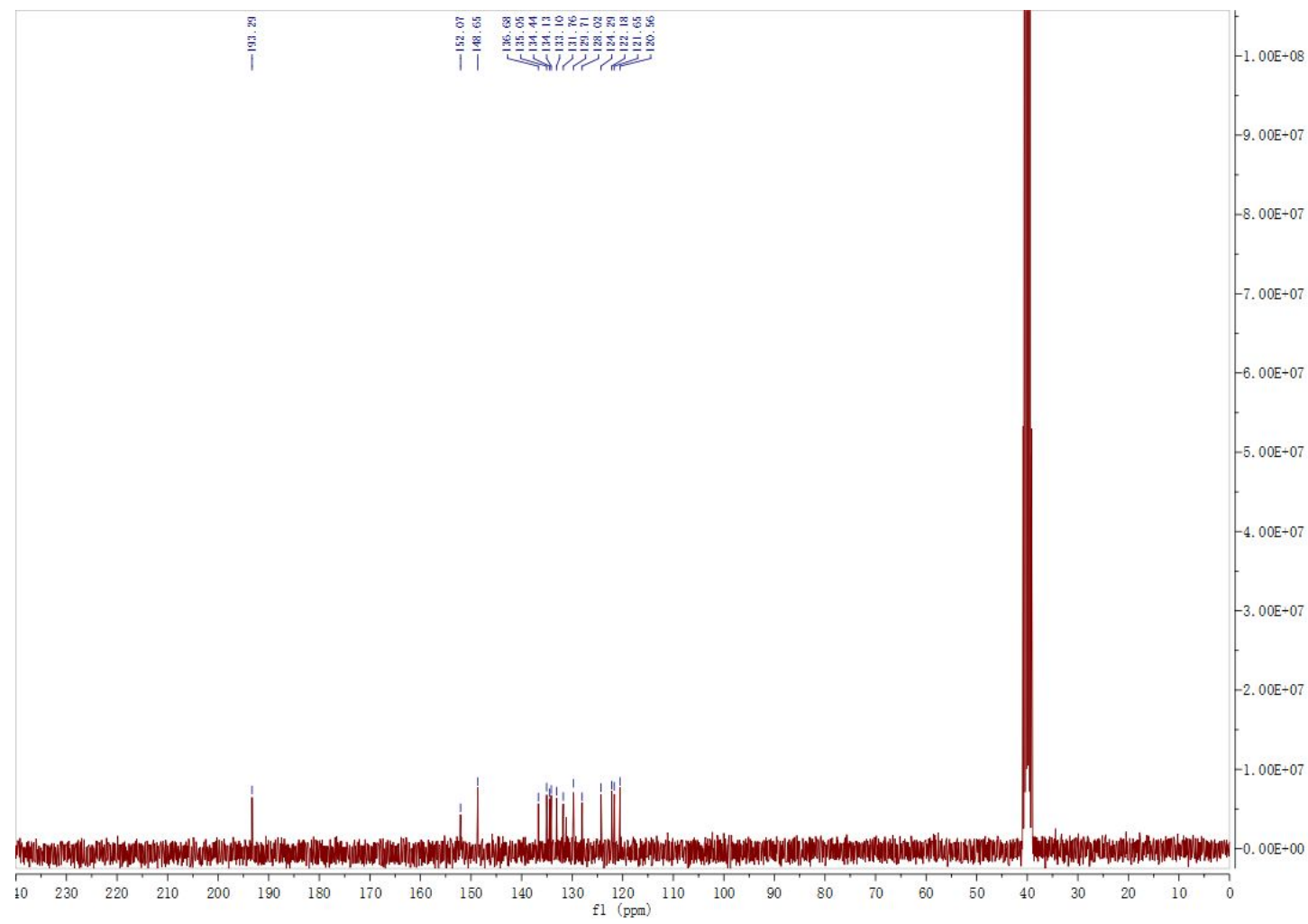


Figure S3. The fluorescence intensity of Probe $1-\mathrm{H}_{2} \mathrm{~S}$ in $\mathrm{CH}_{3} \mathrm{CN}$-water
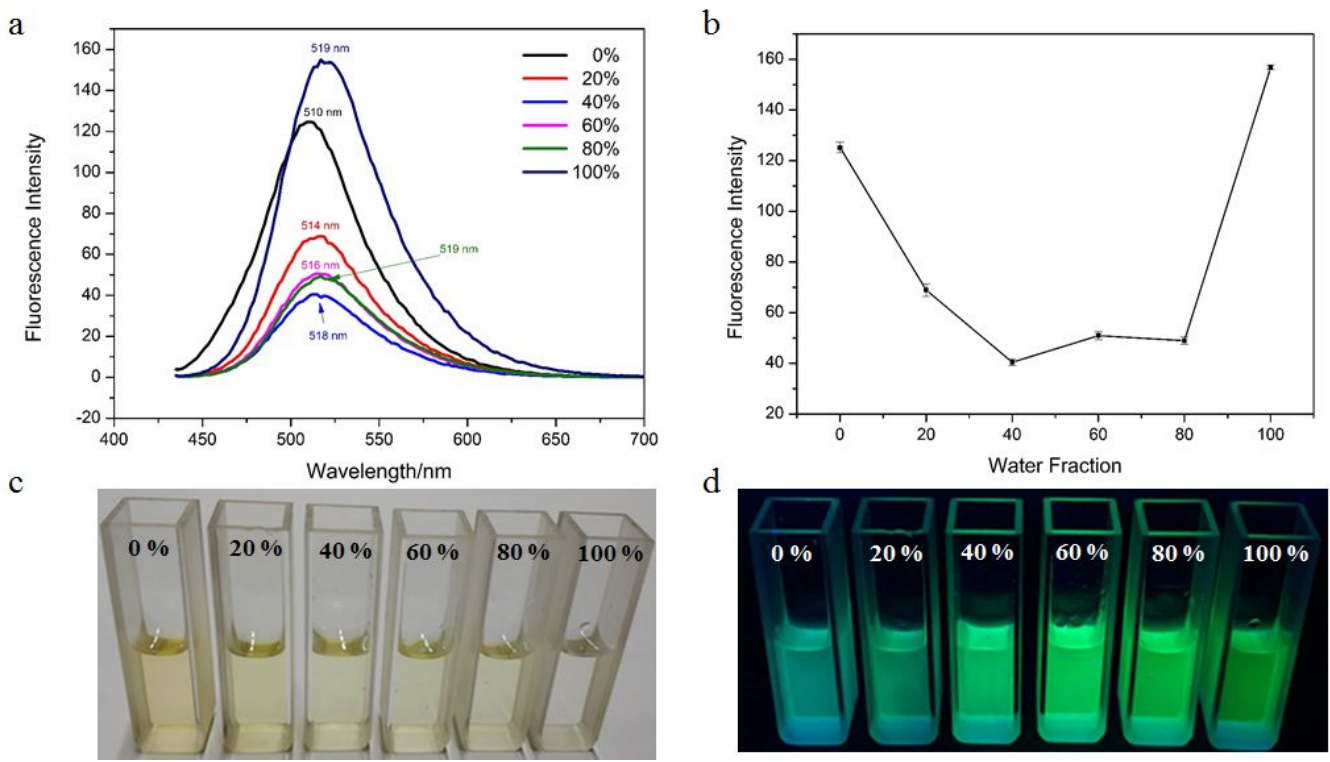

(a) Fluorescent spectra of Probe $1-\mathrm{H}_{2} \mathrm{~S}$ (probe 1, $10 \mu \mathrm{M} ; \mathrm{H}_{2} \mathrm{~S}, 200 \mu \mathrm{M}$ ) in $\mathrm{CH}_{3} \mathrm{CN}$ with increasing water content, $\lambda_{\mathrm{ex}}=425 \mathrm{~nm}$; (b) Plot of the fluorescence intensity of Probe 1- $\mathrm{H}_{2} \mathrm{~S}$ with water content in $\mathrm{CH}_{3} \mathrm{CN}$; (c) Photograph of Probe $1-\mathrm{H}_{2} \mathrm{~S}(10 \mu \mathrm{M})$ in $\mathrm{CH}_{3} \mathrm{CN}$ with different water content under ambient light; (d) Photograph of Probe $1-\mathrm{H}_{2} \mathrm{~S}$ in $\mathrm{CH}_{3} \mathrm{CN}$ with different water content under $365 \mathrm{~nm}$ UV light.

Figure S4. The fluorescence intensity of Probe $1-\mathrm{H}_{2} \mathrm{~S}$ in $\mathrm{C}_{2} \mathrm{H}_{5} \mathrm{OH}$-water
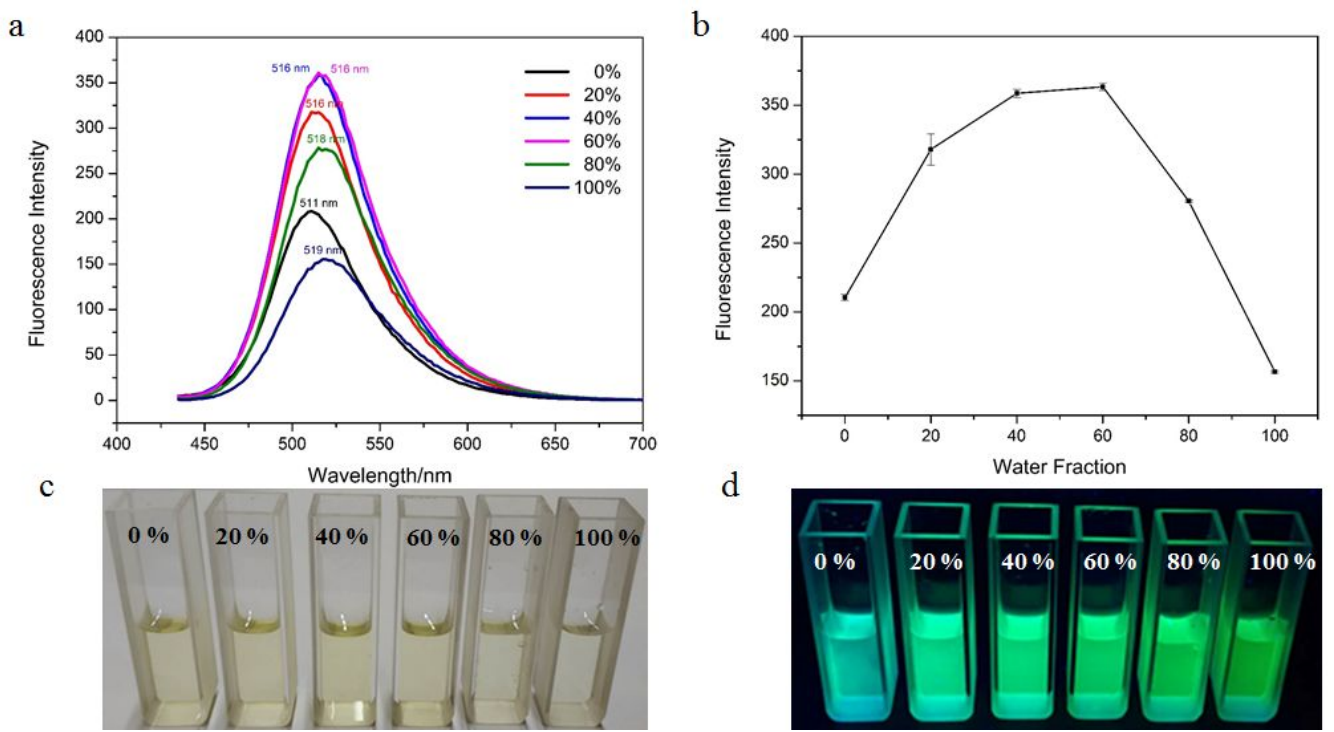

(a) Fluorescent spectra of Probe $1-\mathrm{H}_{2} \mathrm{~S}$ (probe 1, $10 \mu \mathrm{M} ; \mathrm{H}_{2} \mathrm{~S}, 200 \mu \mathrm{M}$ ) in $\mathrm{C}_{2} \mathrm{H}_{5} \mathrm{OH}$ with increasing water content, $\lambda_{\mathrm{ex}}=425 \mathrm{~nm}$; (b) Plot of the fluorescence intensity of Probe 1- $\mathrm{H}_{2} \mathrm{~S}$ with water content in $\mathrm{C}_{2} \mathrm{H}_{5} \mathrm{OH}$; (c) Photograph of Probe $1-\mathrm{H}_{2} \mathrm{~S}$ in $\mathrm{C}_{2} \mathrm{H}_{5} \mathrm{OH}$ with different water content under ambient light; (d) Photograph of Probe 1- $\mathrm{H}_{2} \mathrm{~S}_{\text {in }} \mathrm{C}_{2} \mathrm{H}_{5} \mathrm{OH}$ 
with different water content under $365 \mathrm{~nm}$ UV light.

Figure S5. ${ }^{1} \mathrm{H}$ NMR titration spectra of Probe $1-\mathrm{H}_{2} \mathrm{~S}$

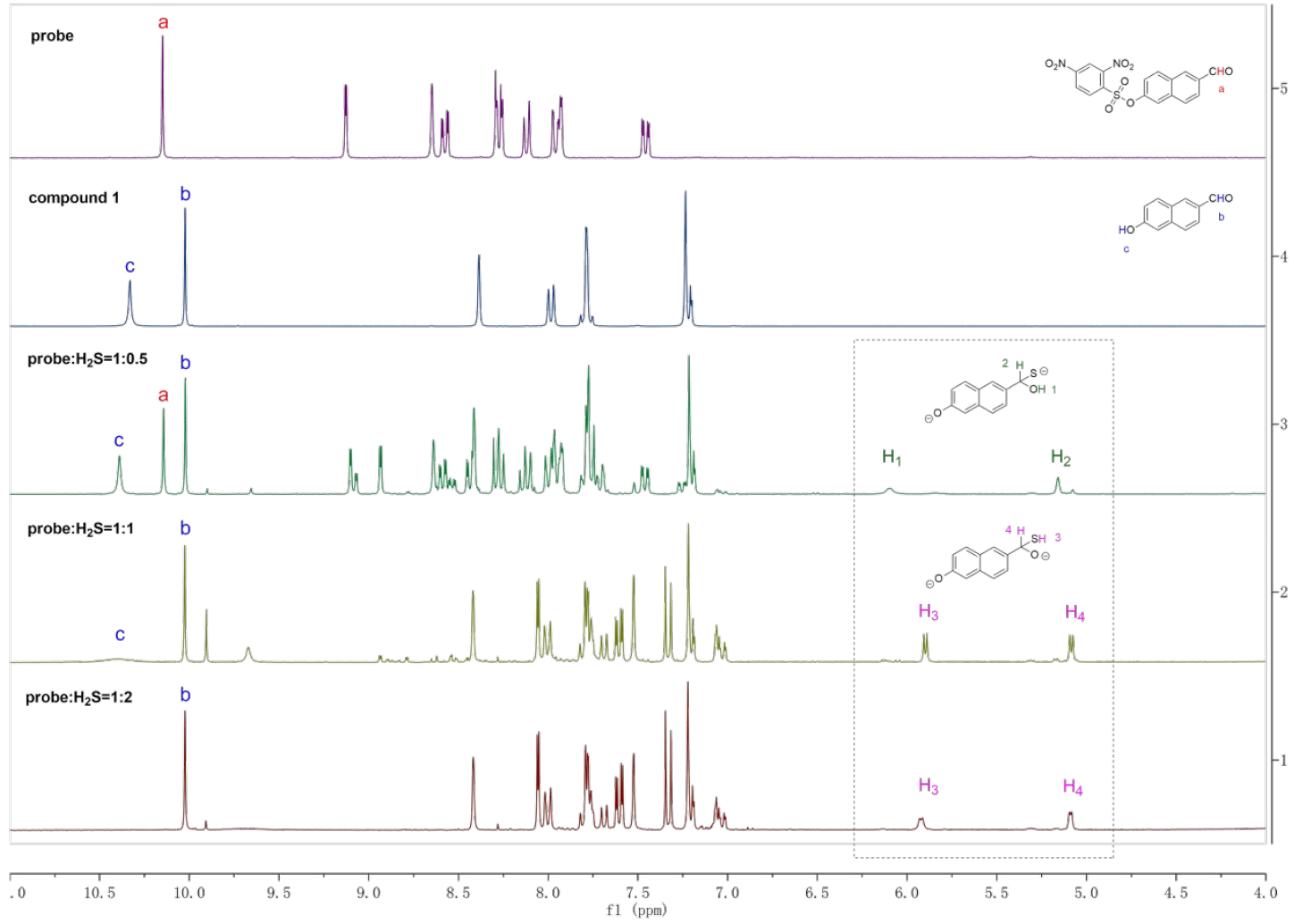

Figure S6. HMQC spectra of compound 1

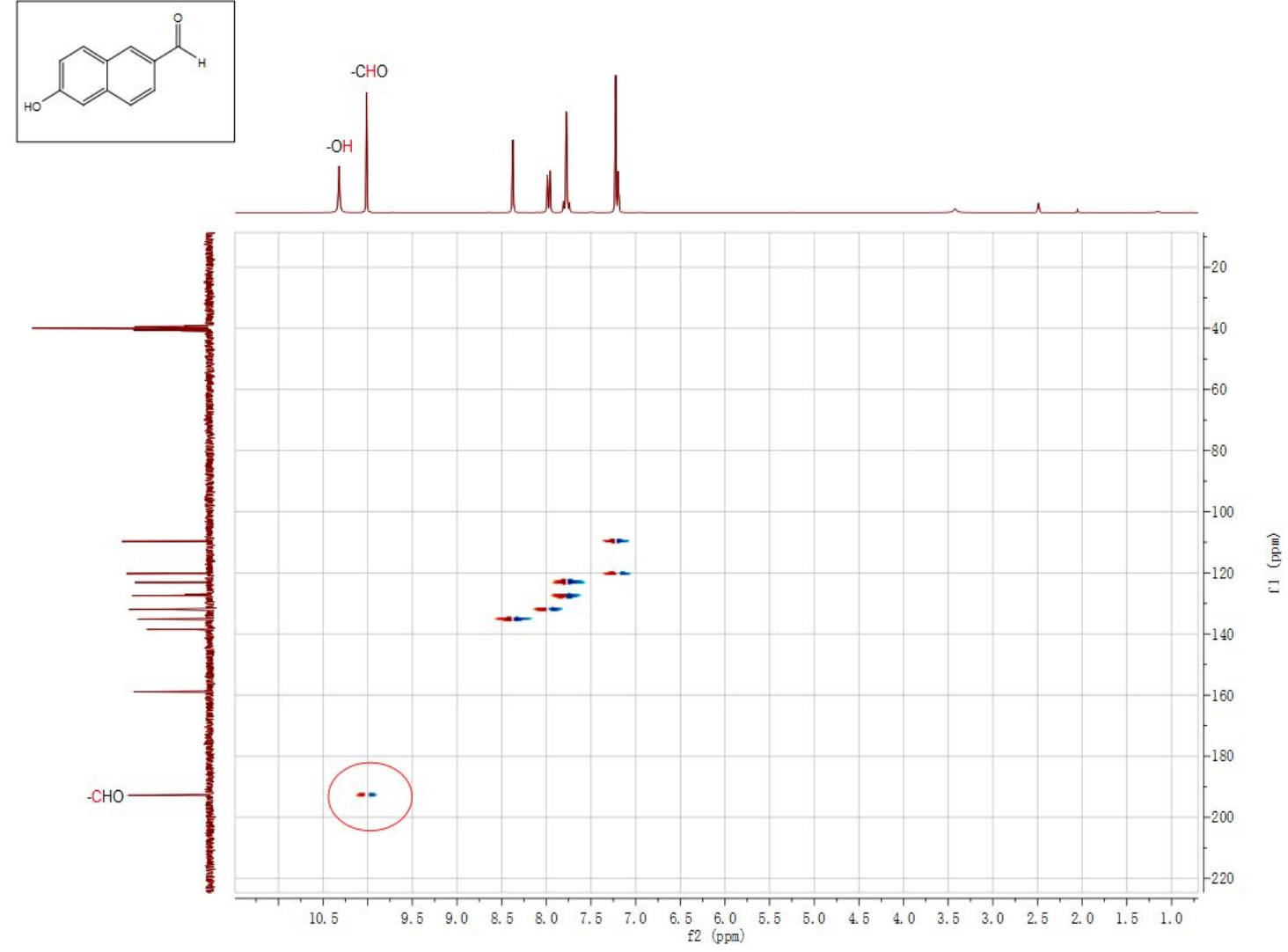


Figure S7. HMQC spectra of Probe $1-\mathrm{H}_{2} \mathrm{~S}$

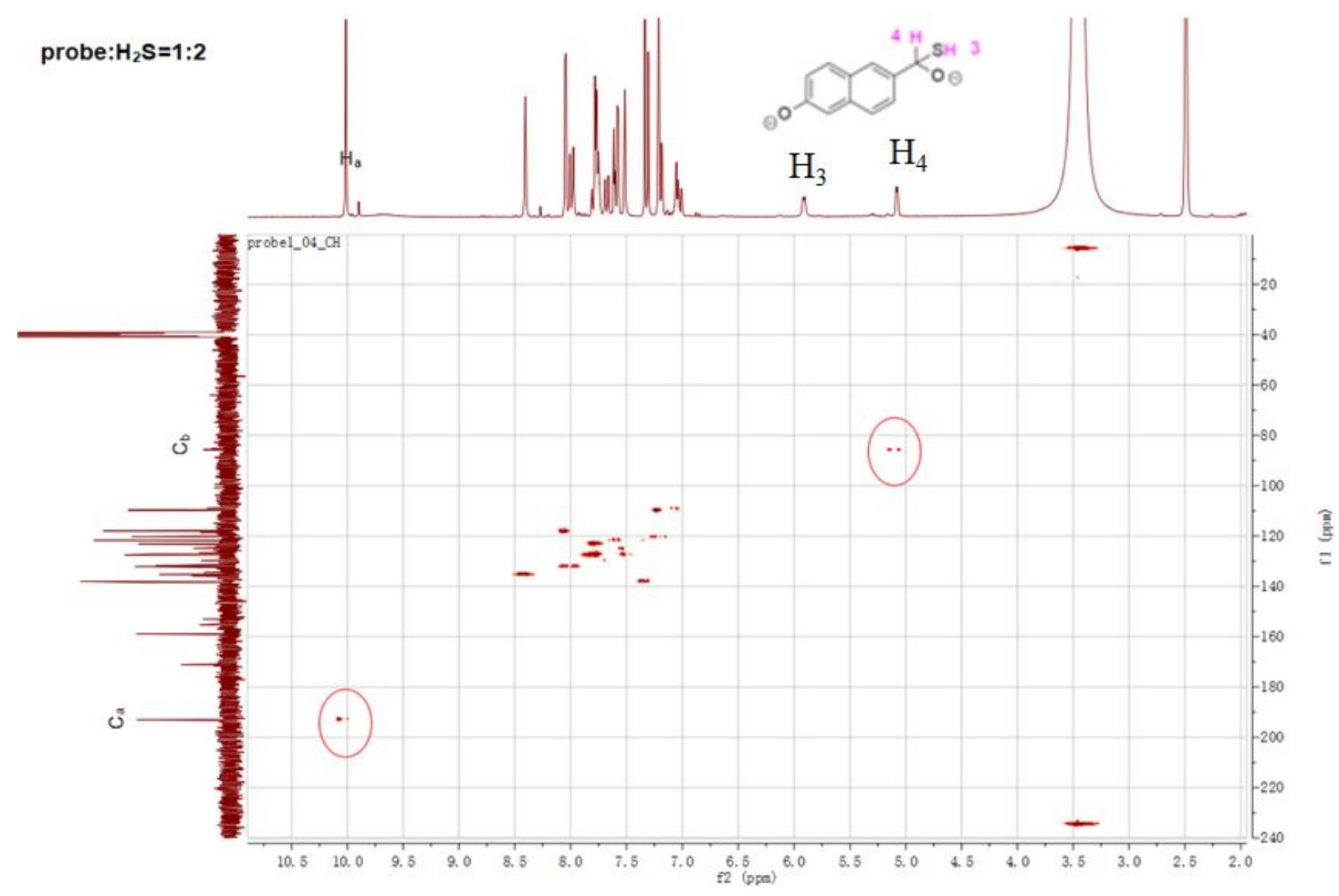

S6 
Figure S8. ${ }^{1} \mathrm{H}$ NMR titration spectra of compound $1-\mathrm{H}_{2} \mathrm{~S}$

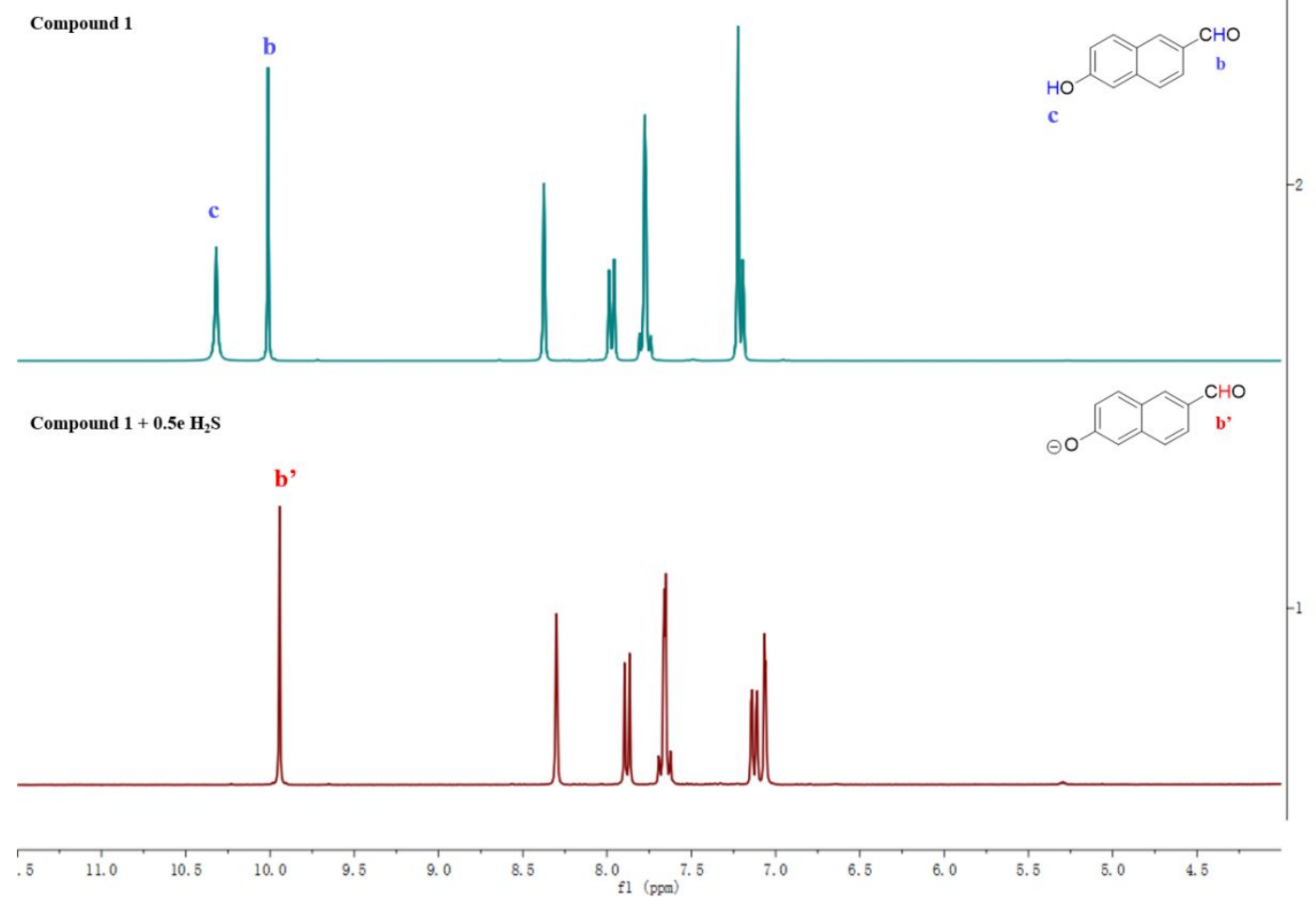

Figure S9. HPLC spectra of Probe 1- $\mathrm{H}_{2} \mathrm{~S}$

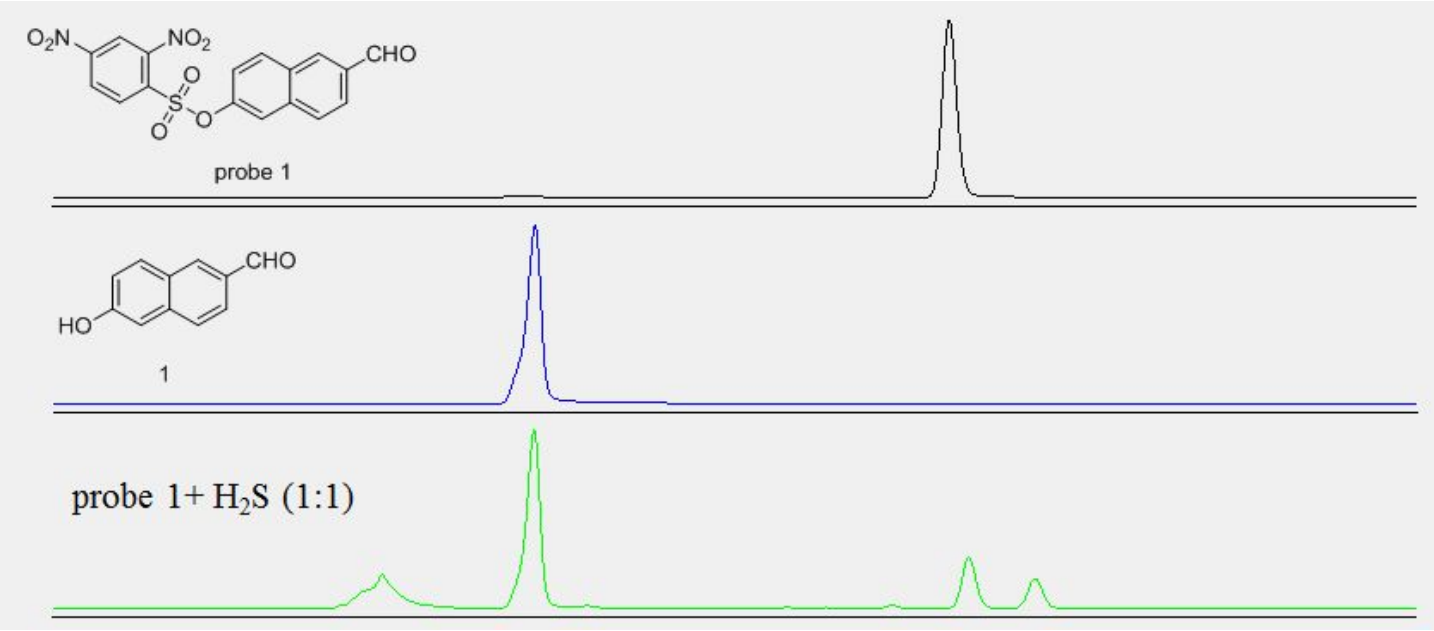




\section{Figure S10. MS spectra of compound 1}

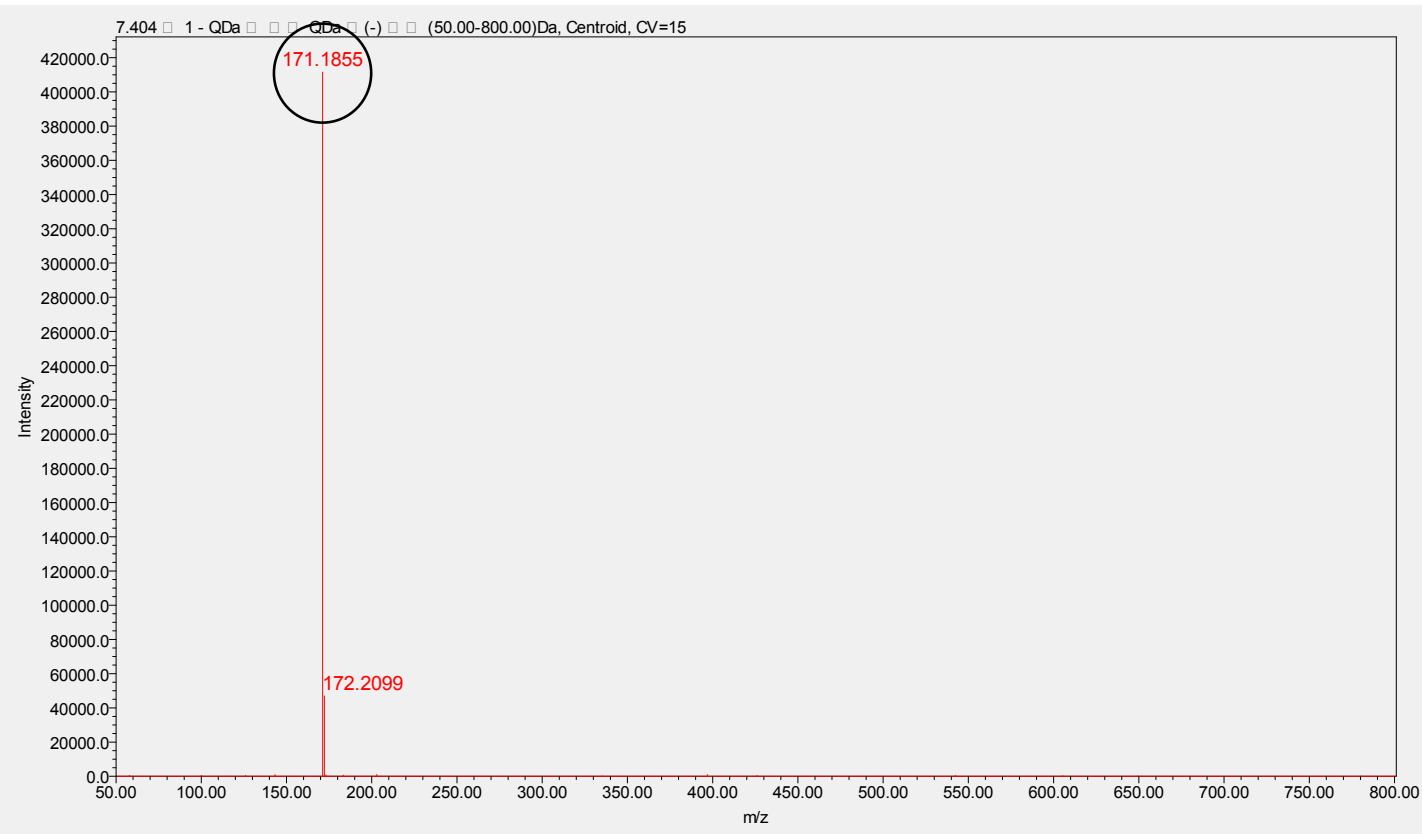

\section{Figure S11. MS spectra of compound 3}

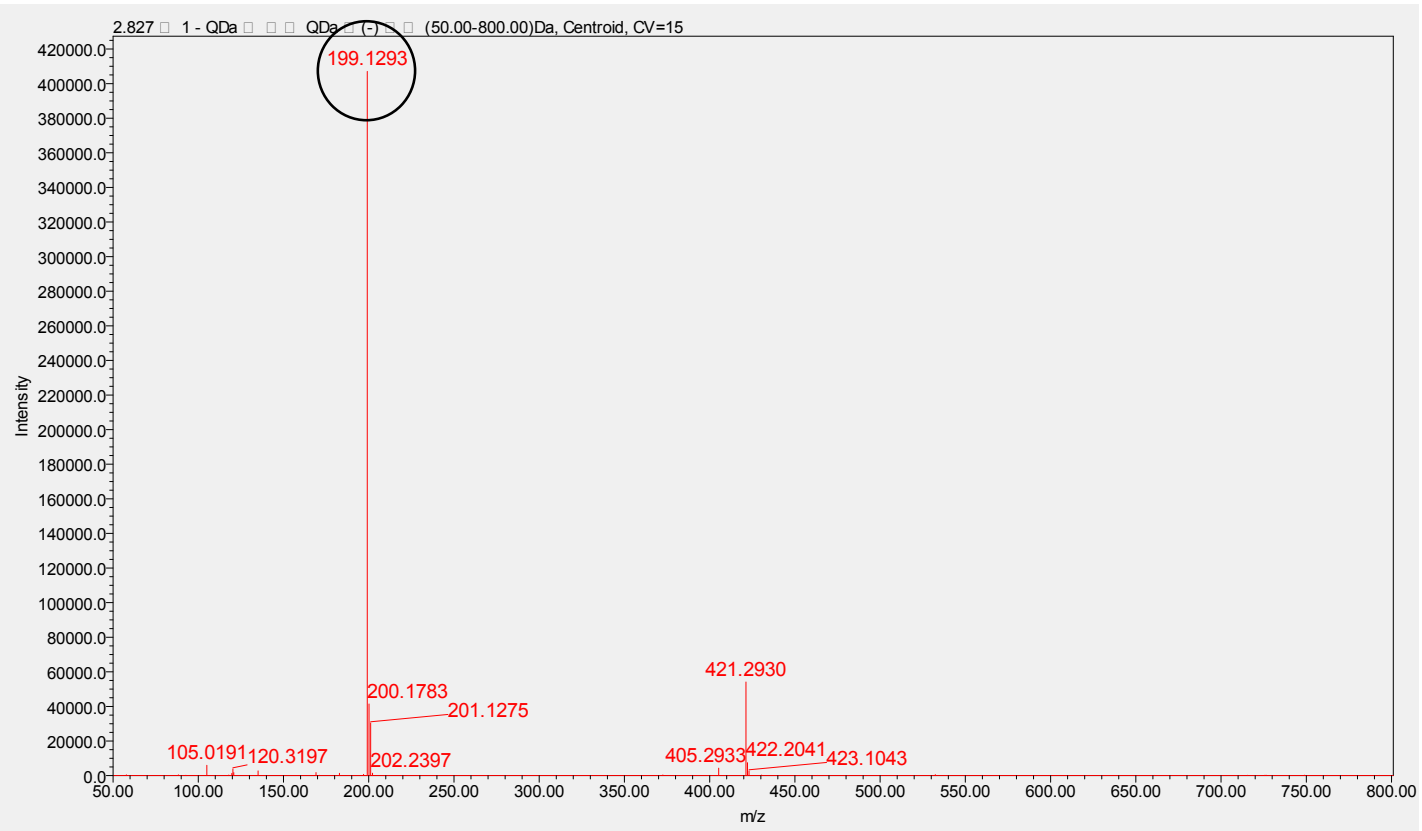




\section{Figure S12. MS spectra of compound 6}

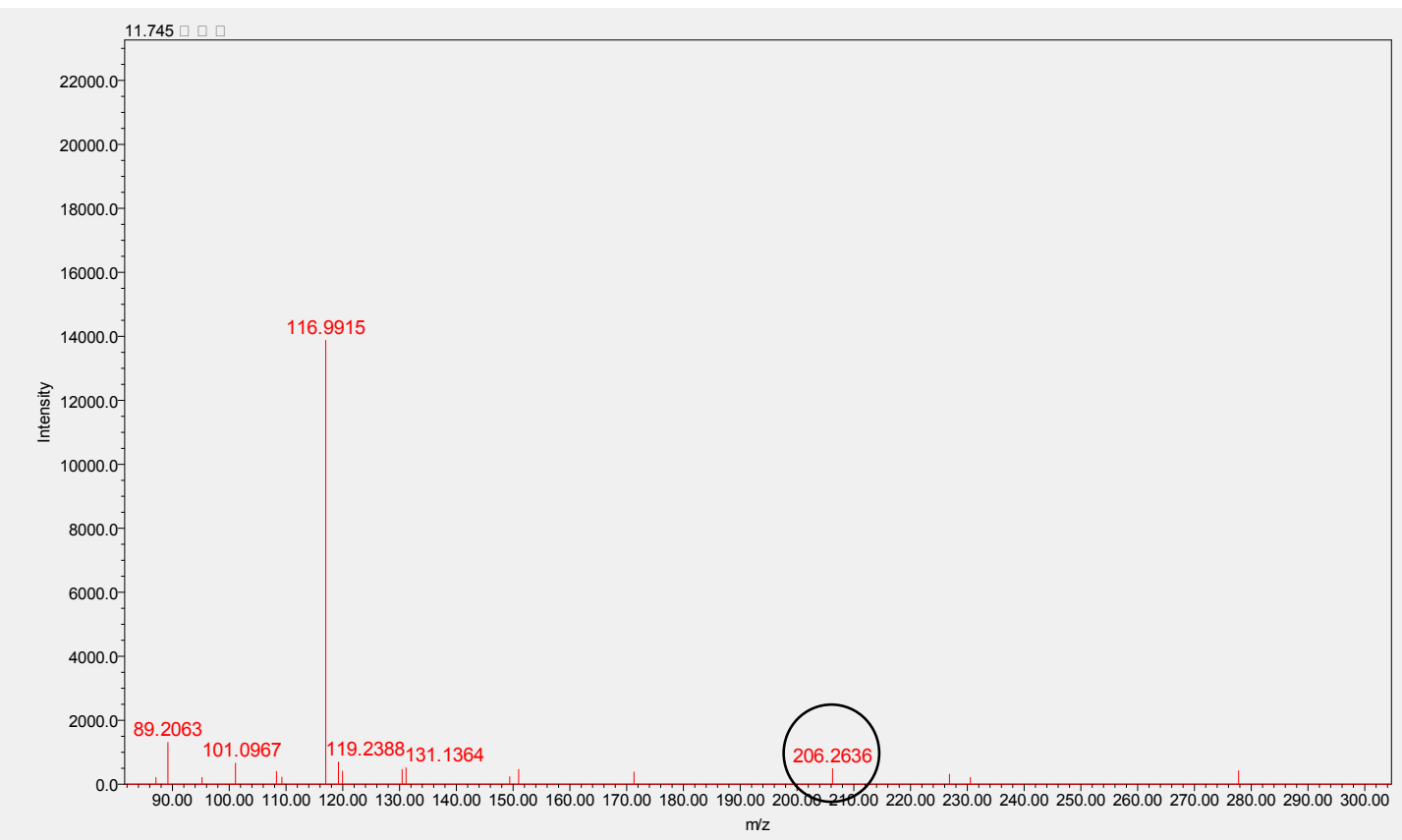

Figure S13. MS spectra of compound 7

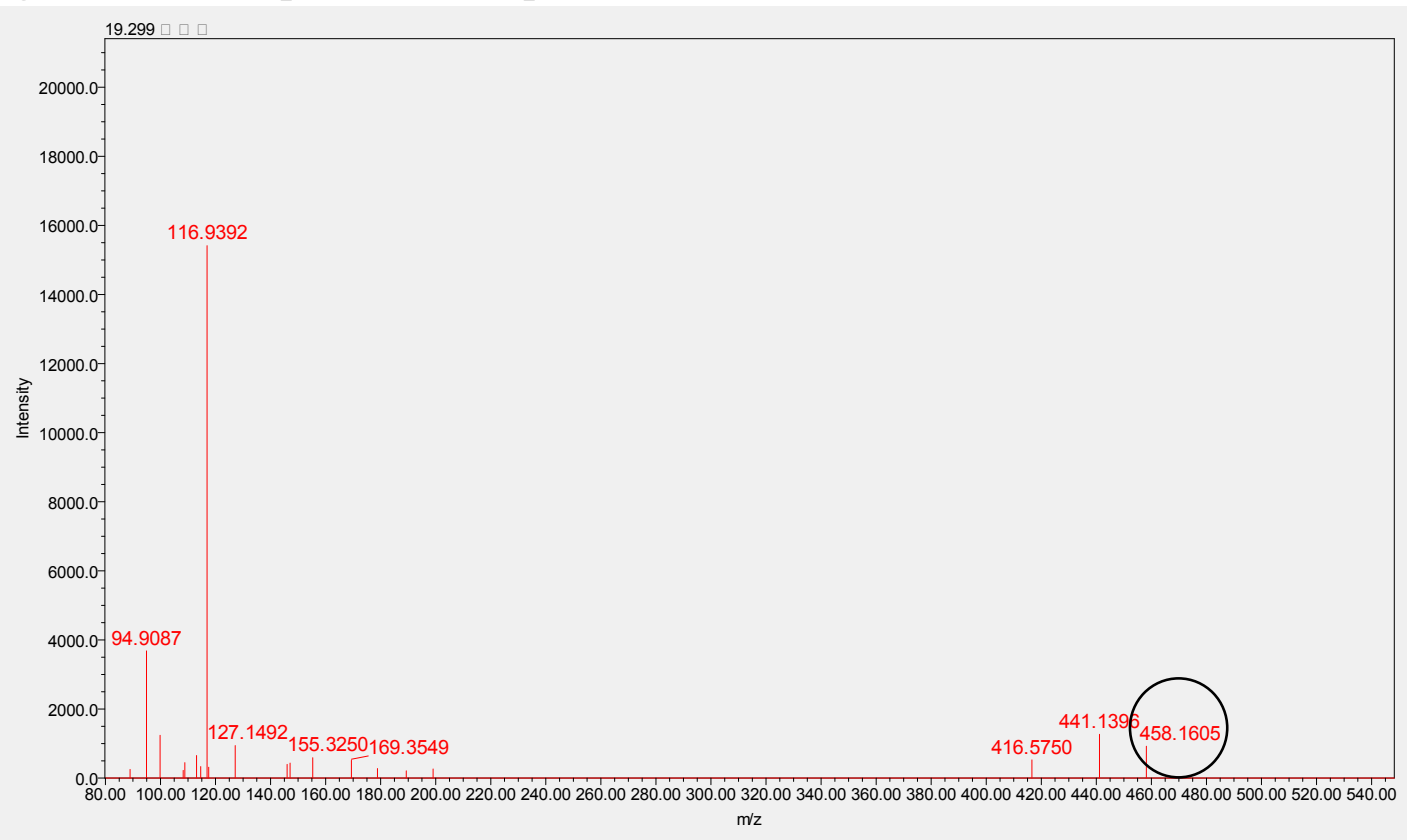


Figure S14. The fluorescence intensity of compound 1

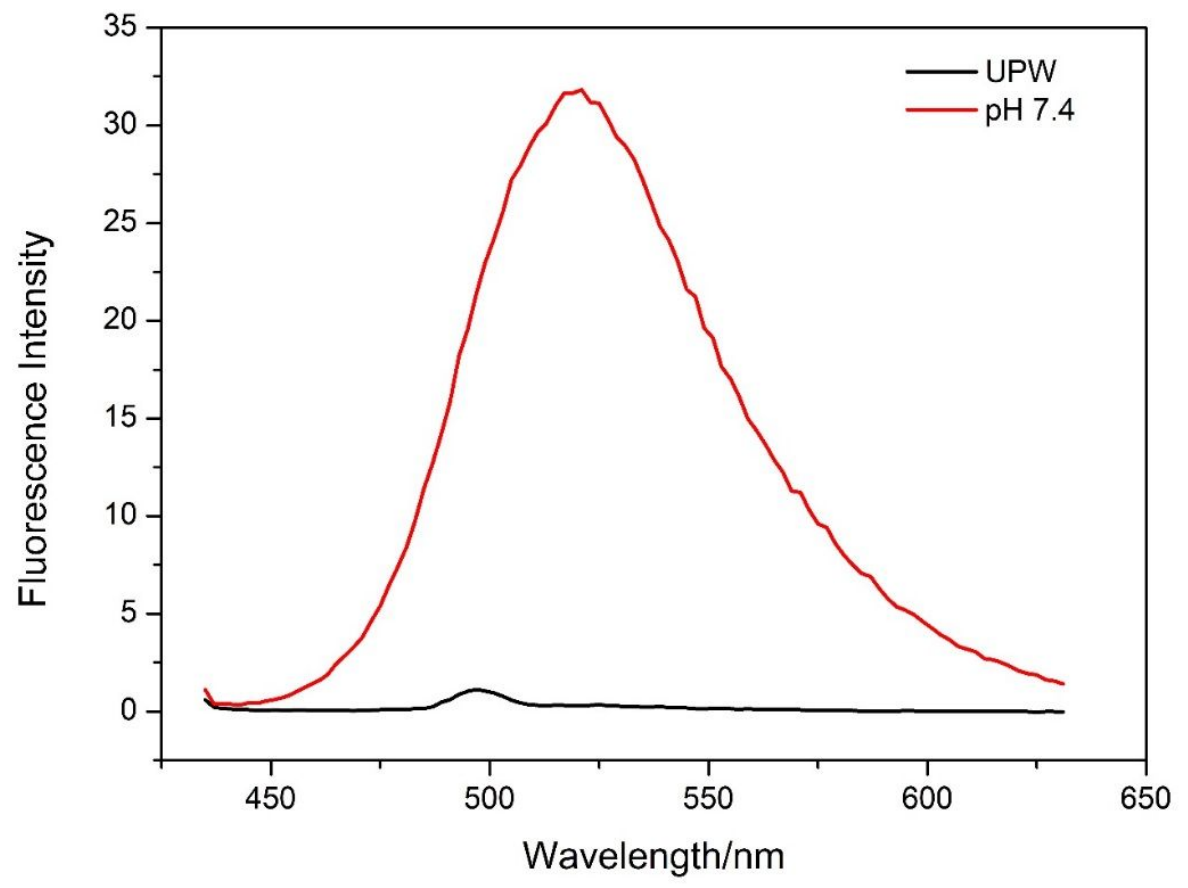

Fluorescent responses of compound $1(10 \mu \mathrm{M})$ added to water and buffer solution ( $\mathrm{pH}$ 7.4) at $25^{\circ} \mathrm{C}$. 
